\title{
TECNOLOGIAS: PROCESSO DE DESTERRITORIALIZAÇÃO DE IDENTIDADES
}

\author{
TECHNOLOGY: PROCESS OF IDENTITIES \\ DETERRITORIALIZATION
}

\author{
Silvelena Cosmo Dias ${ }^{1}$ \\ [ORCID:https://orcid.org/0000-0002-6569-992X] \\ DOI: https://doi.org/10.30612/raido.v14i36.11960
}

\begin{abstract}
RESUMO: Este artigo objetiva problematizar a maneira como materiais de língua inglesa (LI), integrantes do Programa Nacional do Livro Didático (PNLD), se apropriam do discurso sobre as "novas" tecnologias de modo a entrever o imbricamento entre as representaçóes sobre as tecnologias e sobre o aluno. O aporte teórico de sustentaçăo da pesquisa é a perspectiva teórico-metodológica, denominada discursivo-desconstrutiva, balizada pelas teorias do discurso (com base em Foucault), pela desconstruçâo derrideana, que problematiza o que parece evidente e natural, e pela psicanálise lacaniana, no que diz respeito ao sujeito do inconsciente, da falta e do desejo. A análise de natureza discursiva e interpretativa, sobre o funcionamento discursivo, possibilitou rastrear representaçóes de alunos como nativos digitais e autônomos. O discurso sobre as "novas" tecnologias (re-) apresentam-nas, para o aluno, como possibilidades de aprendizagem da LI, de inserçăo no mundo globalizado e digital, e como corolário, a sua integraçấo no mundo do trabalho e ascensăo social.
\end{abstract}

Palavras-Chave: Tecnologias. Representaçōes. Poder-saber.

ABSTRACT: This article aims at problematizing the way how the English language materials, component of the National Textbook Program (PNLD, in its acronym in Portuguese)-appropriatesthe discourse on newtechnologiesinawaythat it waspossible to glimpse the interweaving of the representations of technologies and the student. The theoretical framework of research support is the theoretical-methodological perspective called discursive-deconstructivist, buoyed by theories of discourse, based on Foucault; by the Derridean deconstruction, that problematizes what seems evident and natural; and by the Lacanian psychoanalysis, in regard of the subject of the unconscious, of the lack and of the desire. The discursive and interpretative analysis on discursive functioning made it possible to trace representations of students as digital natives and autonomous. The discourse on "new" technologies (re-) presents them to the student as possibilities of learning the English Language, insertion in the globalized and digital world, and as the consequence, their integration into the labor market and social rise.

Professora do curso de Letras e do PROFLetras (Mestrado Profissional em Letras), da Universidade Federal do Estado de Mato Grosso do Sul, campus de Três Lagoas. Doutora em Linguística Aplicada pela UNICAMP.E-mail: diascosmo@yahoo.com.br. 
Keywords: Technologies. Representations. Power-knowledge.

\section{INTRODUÇÃO}

O livro didático (LD), por ser portador de um conhecimento acumulado, essencial e aceito social e historicamente, dissemina e coloca em circulaçăo o saber, ocupando um lugar de autoridade, de poder, o que o leva a funcionar como um discurso de verdade. No cenário educacional oficial, é massiva a presença do LD no ensino fundamental e médio. Considerado como um recurso imprescindível, em alguns contextos brasileiros ainda, corresponde à única fonte de consulta e pesquisa disponível ao professor (ALMEIDA FILHO, 1994; KLEIMAN, 1992; SOUZA, 1995 apud CORACINI, 2011, p. 17).

Năo se trata de julgar, ou avaliar se é bom ou ruim o material didático - seja no formato de livro ou software, instalado em um computador, com recurso de som, imagem e outras possibilidades de manuseio -, mas de lançar um olhar desafiador, questionador, problematizador sobre as coleçôes de LD de língua inglesa (LI). Essa coletânea foi inserida no contexto escolar oficial do ensino médio, por meio do Programa Nacional do Livro Didático 2012 (PNLD), pela primeira vez em toda a história do ensino de língua inglesa, como língua estrangeira, no sistema público educacional brasileiro. Nesse momento, enquanto professora de língua inglesa, participei do processo de escolha do LD de LI, o que me motivou à pesquisa.

Dessa forma, é objeto relevante e pertinente de estudo científico a temática sobre as novas tecnologias e o ensino de LI, que provém de sua inserçâo no âmbito educacional. Esse fato nos incita a refletir sobre a relevância de pesquisas sobre a maneira como o LD de LI (re-)apresenta a temática sobre as chamadas novas tecnologias. Este artigo tem como objetivo apresentar resultados de uma pesquisa de doutorado - a partir de imagens ilustrativas de jovens atraentes, sorridentes e com expressáo de encantamento frente a aparelhos tecnológicos -, que problematiza a maneira como o material didático de língua inglesa se apropria do discurso sobre as chamadas novas tecnologias de modo a entrever o imbricamento entre as representaçóes sobre as próprias tecnologias e sobre o aluno.

Para tanto, foram selecionados 4 recortes expressivos do eixo intitulado Corpo materializado/virtualizado, que apresentam certas regularidades discursivas acerca da relaçấo do homem com as novas tecnologias; ou seja, como as novas tecnologias se materializam na linguagem năo verbal, tomam corpo, ganham vida e sâo definidas pelo olhar fascinante do ser humano diante do virtual, atribuindo-lhe e constituído-se (de) características peculiares, carregadas de sentido, de efeitos de sentido.

A análise desse funcionamento discursivo é ancorada numa perspectiva teórico-metodológica, denominada discursivo-desconstrutiva (CORACINI, 2010), balizada pelas teorias do discurso (com base principalmente em Foucault), pela desconstruçâo derrideana, que permite problematizar o que parece evidente e natural estabelecido pelo pensamento logocêntrico e dicotômico, característica principal da sociedade ocidental, e pela psicanálise lacaniana, no que diz respeito ao sujeito descentrado, cindido, sujeito do inconsciente, da falta e do desejo, constituído pela linguagem porosa, obscura e equívoca. Apesar de esse encontro teórico ser revestido por pensadores de áreas diferentes, todos realizam uma problematizaçăo, o que permite um diálogo 
profícuo e abundante no que diz respeito à concepçăo de sujeito, discurso e linguagem, tornando-se relevante e pertinente para a base teórica, deste trabalho, e para o desenvolvimento da análise.

\section{OS DISCURSOS SOBRE}

Na concepçâo foucaultiana, o discurso, enquanto prática social, funciona como um discurso de verdade que engendra saber, na sua relaçăo intrínseca com o poder. Nessa perspectiva, Foucault (1995b, p. 243) ressalta que a açáo é a condiçâo para a existência do poder, ou seja, o poder só existe quando colocado em açăo, năo agindo "direta e imediatamente sobre os outros, mas" agindo "sobre sua própria açâo". Nesse ponto, é possível estabelecer certa relaçăo entre o discurso sobre as tecnologias e as próprias tecnologias, considerando que aquele tenta colocar estas em açăo nas páginas impressas do LD de LI. Além disso, o discurso sobre as "novas" tecnologias evidencia as representaçôes que o autor do LD tem sobre as chamadas novas tecnologias que sáo materializadas em elementos linguísticos nos LDs do PNLD.

Neste sentido, o LD de LI é visto como uma prática discursiva inserida no discurso didático pedagógico e no discurso político educacional. Vale mencionar que práticas discursivas, no sentido foucaultiano, săo "um conjunto de regras anônimas, históricas, sempre determinadas no tempo e no espaço, que definiram, em uma dada época e para uma determinada área social, econômica, geográfica ou linguística, as condiçóes de exercício da funçăo enunciativa" (FOUCAULT, 2009a, p. 133). As práticas discursivas, argumenta Foucault (2009a), implicam relaçóes de poder, constituem domínios de saber, objetos, conceitos, técnicas, sujeitos, desejos e subjetividades.

Deste modo, o LD de LI é perpassado por vários discursos, que agregam diferentes saberes constituídos histórica e socialmente, em uma determina época. A análise depreendida em livros didáticos por Coracini (2003c, p. 200) permite afirmar que "o discurso didático, como todo discurso pedagógico, apresenta-se como sendo a verdade [...] verdade sobre os fatos, sobre a natureza, os objetos, sobre o processo de ensino-aprendizagem, sobre a língua". A maneira como o LD se apresenta com conceitos estáveis, conteúdos organizados, dados estatísticos e fotos para comprovar o que diz e, sobretudo, com "uma certa visáo de cientificidade que atravessa o discurso pedagógico", produz efeitos de discurso de verdade (CORACINI, 2003c, p. 200). Em busca de uma verdade absoluta, o discurso pedagógico "se constrói na certeza do que afirmam as autoridades de reconhecido saber, na ilusăo da total ausência do que é subjetivo e transitório" (CORACINI, 2003a, p. 326).

Para que os LDs de LI, integrantes do PNLD, se constituam como tal, é necessário selecionar certos procedimentos estabilizantes, ordenados pelas instâncias governamentais, para escrever no "papel vegetal" com a sensaçăo de que se inscreve no espaço virtual, no corpo, no corpus. É preciso (re)conhecer as regras para entrar no jogo, já que também é feito de interdiçôes, pois "năo se pode falar de tudo em qualquer circunstância [...], năo se pode falar de qualquer coisa" (FOUCAULT, 1995a, p. 9), ou seja, nâo se pode escrever qualquer coisa no LD. É preciso seguir os regulamentos estabelecidos no Edital do PNLD 2012 (BRASIL, 2011a), ou seja, é preciso entrar na ordem do discurso político educacional, atender à demanda desse discurso, para que autores e editores se 
inscrevam/escrevam n(o) LD de LI. Segundo Mascia (2002, p. 19-20), o discurso político educacional:

[...] manifesta os dispositivos reguladores das práticas educacionais. É político porque é veiculado por instâncias às quais săo delegados poderes e autoridade sobre a educaçăo no que tange tanto às decisóes, quanto aos rumos desta. É educacional porque tem como objetivo a educaçáo e o saber veiculado por ela. Nesse sentido, postulamos como DPE o discurso do poder-saber das práticas educacionais.

O discurso político educacional se manifesta como uma teia de dupla funçăo: político porque as instâncias governamentais estabelecem normas reguladoras de práticas e, educacional porque determinam que tipo de saberes deve ser veiculado pelo LD e pela escola. Portanto, "ninguém entrará na ordem do discurso se náo satisfazer a certas exigências ou se năo for qualificado para fazê-lo" (FOUCAULT, 1995a, p. 37).

O discurso político educacional, instituído social e educacionalmente, formalizado nas Orientaçóes Curriculares para o Ensino Médio - documento elaborado pelo Ministério da Educaçăo (BRASIL, 2006) - visa normatizar năo só a prática do professor em sala de aula, mas principalmente, a produçáo de material didático. O documento enfatiza que o principal objetivo do ensino e aprendizagem de LI é a formaçăo cidadă, profissional, acadêmica ou pessoal. Além disso, uma de suas premissas é a inclusăo do aluno no mundo digital e "globalizante", bem como "o acesso às tecnologias, às novas formas de comunicaçâo, ao conhecimento por elas gerado, pois esse acesso representa oportunidades de participaçăo ou mesmo ascensấo social" (BRASIL, 2006, p. 95).

Para dar conta, segundo o documento oficial, desses novos e complexos usos da linguagem, das novas modalidades de texto (imagem, som, hipertexto), dos termos técnicos e específicos da informática em língua inglesa, bem como do emprego de uma linguagem específica à comunicaçấo mediada pelo computador, surge o conceito de "multiletramento" que "se baseia numa visăo heterogênea, plural e complexa de linguagem, de cultura e de conhecimento, visăo inserida em contextos socioculturais" (BRASIL, 2006, p. 109). Tais "conhecimentos novos" agregados aos "velhos" possibilitarâo a transformaçăo e a geraçăo de novos conhecimentos (BRASIL, 2006, pp. 95-109).

Essas assertivas do documento oficial dâo margem para afirmar que elas ressoam no Edital 2012 e, consequentemente, fazem eco na coletânea do material didático de LI. Por meio das imagens e fotos ilustrativas de jovens capturados pela tecnologia digital, da atividade pedagógica que explora termos e expressôes da área de tecnologia e uma amostra de uma suposta profissâo que necessita de conhecimentos tecnológicos - que constituem o corpus de análise, neste trabalho -, asseguram a consonância com as Orientaçóes Curriculares para o Ensino Médio. Desse modo, podemos afirmar que o discurso político educacional age sobre o discurso didático pedagógico na medida em que o LD de LI aborda o discurso sobre as tecnologias, concedendo a elas um lugar de status, de autoridade, de saber, portanto, de poder.

A respeito da educaçăo como direito de todo e qualquer cidadăo na sociedade, Foucault (1995a, p. 44) argumenta que "todo o sistema de educaçáo é uma maneira política de manter ou de modificar a apropriaçâo dos discursos, com os saberes e os poderes que eles trazem consigo". Compreendemos esse dizer como uma crítica ao saber institucionalizado, legitimado como verdade e aceito sem maiores questionamentos, 
quando Foucault (1999) questiona o modo de produçăo, circulaçăo e funcionamento do saber, em suas relaçóes com o poder, nos discursos, principalmente, neste caso, os que atravessam o LD.

O autor do LD de LI é considerado como aquele que se submete aos dizeres dos documentos oficiais, que interpreta esses dizeres, reúne-os em sua obra destinada a um determinado público - o órgâo político educacional (MEC) que o avalia e seus usuários: professor e aluno. Entendemos o autor do LD de LI como escritor, no sentido foucaultiano, alguém que assume a funçâo-autor (FOUCAULT, 2009b) - aquele que coloca em circulaçăo e em funcionamento certos discursos. Ao mesmo tempo em que o autor de uma obra assina seu nome, ele precisa de uma contra-assinatura, o reconhecimento social, institucional. Como bem lembra Derrida (2012, p. 35), "se năo há contra-assinatura, a assinatura náo existe", o LD de LI só é reconhecido como tal se o PNLD o legitimar. No momento em que a obra é contra-assinada, ou seja, é selecionada, aprovada, reconhecida como parte integrante do PNLD, ela é posta em circulaçăo, é dada à disseminaçấo de sentidos pelo seu público leitor.

A problematizaçăo que engendramos diz respeito à maneira como tanto o discurso político educacional quanto o discurso didático pedagógico se apropriam do discurso contemporâneo sobre as "novas" tecnologias - de forma que essa problematizaçấo nos conduz a observar que o sujeito enunciador, nesse caso, o autor do LD de LI, constrói representaçôes que năo só se restringem às tecnologias, mas que também contemplam o estudante do ensino médio.

\section{REPRESENTAÇÕES EM TEMPOS DE TECNOLOGIZAÇÃO}

Para problematizarmos a maneira como o aluno e as tecnologias săo representados pelo/no LD de LI, ao puxar fios do discurso sobre as "novas" tecnologias, é relevante e imprescindível trazermos para nossas discussôes as concepçôes de representaçâo e identificaçâo, já que o material didático procura se identificar com o aluno, apresentando características que julgam ser próprias do aluno. Abordar as questôes conceituais sobre representaçâo e identificaçâo significa nâo considerá-las fixas e estáveis, mas promovendo deslocamentos, descentramentos, movimentos descontínuos e dispersos com relaçăo à verdade e ao saber, constituídos sempre em práticas sociais (FOUCAULT, 1995a; 2009a), portanto, numa relaçăo com o outro (neste caso, na relaçáo com o LD).

O representar é peculiar e singular, há representaçăo para tudo que existe no mundo. Representar é o trazer de novo, é apresentar e, ao apresentar-se novamente (re-) apresenta-se aquilo que estava ausente. No entanto, a cada nova (re-)apresentaçâo algo se repete e algo se faz diferente, nunca torna presente a mesma coisa, nunca torna algo completamente novo e diferente, na perspectiva derrideana. Um significante só tem sentido em relaçâo a outro significante. Ele năo tem presença totalizante do sentido e năo há nenhum significante que recubra totalmente o outro. Como bem se posiciona Derrida (1986), na linguagem, só há metáfora e metonímia. Sendo a linguagem fundamentalmente metafórica, năo há acesso à origem, à verdade pura. $\mathrm{O}$ autor fala de deslizamento incessante de um significante para outro, num continuum. É um eterno adiamento com furos, nunca chega num sentido único. É repetiçâo do eterno retorno, mas nunca o mesmo inteiro, é o mesmo e o diferente. 
Neste ponto, é possível estabelecer um diálogo com as reflexôes psicanalíticas de Lacan (2007) sobre o enodamento entre o real, simbólico e imaginário no sistema de representaçăo do sujeito e das coisas existentes no mundo. $O$ escrever é da ordem do simbólico; representar é da ordem do imaginário e existir é da ordem do real. Há o que pode e o que năo pode ser simbolizado. No próprio simbólico, nem tudo se diz, porque há algo do real no simbólico, há o inomeável e năo há possibilidade de simbolizaçăo do real, o real nâo se simboliza. O imaginário instaura o tempo e o espaço e săo estes que determinam o estar no mundo. A coisa em si é representável na própria coisa, porém, ao dizer, imagina-se e algo falta, porque ninguém imagina algo que seja igual, năo há o mesmo. O real parte do princípio de que algo existe - é a partir da existência que se chega no representável, ou seja, o imaginário. Apesar de a representaçăo estar na ordem do imaginário, ela precisa do simbólico para ser mediada; ou seja, da língua(gem), que năo consegue abarcar o todo. Assim, algo escapa, algo resta, algo năo se explica, é o inexplicável: o real. E é justamente porque algo escapa que existe o real. Por isso que, nessa perspectiva discursivo-desconstrutiva, baliza-se a incompletude tanto do sujeito quanto da língua(gem).

Segundo as premissas lacanianas, o eu nâo se identifica com toda e qualquer imagem que vê, nem com o tudo que lhe é dito. Fundamentado em Lacan, Nasio (1997, pp. 116-117) afirma que "o eu só se identifica seletivamente com as imagens em que se reconhece, [...]". Essas imagens, eleitas e internalizadas pelo inconsciente, inscrevem-se na ordem do imaginário, perpassadas pela ordem do simbólico, uma vez que aquelas săo estruturadas via linguagem, concebendo uma relaçăo com o interdiscurso (memória discursiva).

A noçăo de identificaçăo formulada por Lacan (1998) permite-nos compreender que o sujeito, na constituiçăo de sua identidade, se identifica com traços do discurso do Outro, da ordem do simbólico, do inconsciente, lugar de registro, de inscriçăo. A identificaçăo, para Lacan (1998, p. 92), é sempre "parcial e tateante", diferentemente da imitaçấo, que se caracteriza "năo somente como a assimilaçăo global de uma estrutura, mas como a assimilaçâo virtual do desenvolvimento implicado por essa estrutura". Dito de outro modo, a imitaçăo implica na reproduçăo de traços do outro, ao passo que a identificaçáo implica na absorçăo desses traços, que funcionam em potencial, na constituiçâo do sujeito, como dimensâo do outro. Essa dimensâo do outro pode ser observada no material didático, ao apropriar-se do discurso sobre as "novas" tecnologias de tal forma a veicular representaçōes sobre as próprias tecnologias e sobre o aluno, como exemplo, os recortes discursivos trazidos aqui.

Em termos precisos, se a identificaçâo imaginária dá origem ao eu (instância consciente), "a identificaçăo simbólica consiste precisamente no nascimento do sujeito do inconsciente, compreendido como a produçâo de um traço singular que se distingue ao retornarmos um a um cada significante de uma história" (NASIO, 1997, p. 114). Esse traço singular é tido por Lacan (1998) como traço unário, na medida em que sua funçâo é distintiva, marcando uma diferença a cada retomada, a cada repetiçâo, sublinhando a singularidade do sujeito. Desse modo, "o sujeito do inconsciente é [...], ele próprio, o traço que unifica o conjunto dos significantes" (NASIO, 1997, p. 114).

Para Lacan (1998), o traço unário - lugar da falta, o traço distintivo - está na base de toda identificaçấo, marca a vida do sujeito e impóe-lhe um desejo, uma busca 
incessante por preenchimento dessa falta. Traço de diferença, por meio do mecanismo da identificaçăo, pode ser assimilado por diversos sujeitos ao mesmo tempo. Ao tornar-se traço de unificaçăo, multiplica-se, torna-se traço distintivo e singular a cada repetiçăo, que jamais pode ser o mesmo, marcando, assim, sua falta, sua incompletude. Ao encontro dessa concepçăo, Coracini (2003b, p. 243) argumenta que a identidade do sujeito é resultado "de uma 'falta': falta de inteireza que procuramos preencher (sem jamais conseguir), a partir de nosso exterior, pelas formas através das quais nós imaginamos ser vistos por outros: sei quem sou em relaçáo com o outro que eu náo posso ser".

É importante salientarmos que sustentamos a visâo de que a identidade do sujeito é produzida via linguagem e que o seu efeito de completude se dá no funcionamento discursivo. Assim, corroboramos a visăo de Coracini (2003b, p. 243) que afirma que "apesar da ilusâo que se instaura no sujeito, a identidade permanece sempre incompleta, sempre em processo, sempre em formaçăo", sendo apenas "possível capturar momentos de identificaçăo do sujeito com outros sujeitos, fatos e objetos".

Os processos identificatórios năo acontecem de forma estável e pacífica e nunca podem ser tomados como prontos. Eles sáo construídos em embates e lutas pelo poder e saber, legitimando verdades e impondo ao sujeito formas de representaçóes, de sentido, de dizer e de se dizer. Se, na sociedade disciplinar (FOUCAULT, 1999), sua característica principal é a demarcaçăo do espaço, do tempo e da distribuiçăo dos sujeitos em lugares como nas escolas, nos quartéis, nas prisōes, nas fábricas, impondo-lhes condutas e identidades, nas sociedades ditas de controle, pretende-se docilizar corpos e mentes, como forma de exercício do poder. Hoje, o computador e a internet funcionam como dispositivos disciplinares e dispositivos de controle, que (des)articulam, (re)produzem e (des)ajustam atitudes, comportamentos e subjetividades, portanto, identidades.

Os "efeitos identitários" das experiências online na vida, segundo Turkle (1996, 15-17), sāo marcados por fragmentaçâo, ficçăo e fantasias identitárias, construídos via linguagem, na relaçâo com outro - mesmo que esse outro (e)s(t)eja (n)a tela do computador -, remetendo-nos ao dizer de Coracini (2007, p. 23), para quem a identidade é "interpretaçăo, ficçăo, imagens que constituem o imaginário do sujeito - como ele se vê e acredita ser visto -, construindo, assim, [...] os momentos de identificaçăo que permitem a ilusăo da permanência de uma certa identidade".

Dessa maneira, vale mencionar que as novas tecnologias inseridas nas práticas pedagógicas da sala de aula parecem funcionar como um dispositivo de controle, que permeia relaçóes, con(e)voca certas representaçóes das próprias tecnologias e de seus usuários, principalmente, o aluno. A noçấo de dispositivo é referida no sentido discutido por Deleuze, a partir de Foucault. Deleuze (1996) define dispositivo como "um conjunto multilinear, composto por linhas de natureza diferentes", quebradiças, bifurcadas, que possibilitam derivaçôes. O dispositivo é perpassado por linhas de forças, sendo essas a dimensâo do poder - poder como dimensấo do espaço - compostas com o saber, como o poder.

Diante do exposto, vemos o discurso sobre as "novas" tecnologias no LD de LI como um dispositivo, uma vez que, de algum modo, esse discurso é eficaz para capturar, modelar e controlar condutas, ou seja, agenciar seus usuários: o estudante do ensino médio. As chamadas novas tecnologias enquanto dispositivo e agenciamento conduzem a determinados modos de pensar e agir fundados em um imaginário de liberdade. Entendemos agenciamento, conforme discutido por Deleuze \& Guattari (2011), como 
uma combinaçăo de elementos heterogêneos dando origem a algo novo. A esse respeito, Deleuze \& Guattari (2011) destacam que o movimento concomitante e mútuo dos agenciamentos constitui territórios que compreendem dentro de si, essencialmente, dois segmentos: desterritorializaçâo e reterritorializaçăo, no sentido de abandono e criaçâo.

O território pode se desterritorializar, isto é, abrir-se, engajar-se em linhas de fuga e até sair do seu curso e se destruir. A espécie humana está mergulhada num imenso movimento de desterritorializaçăo, no sentido de que seus territórios "originais" se desfazem ininterruptamente com a divisâo social do trabalho, com a açāo dos deuses universais que ultrapassam os quadros da tribo e da etnia, com os sistemas maquínicos que a levam a atravessar cada vez mais rapidamente, as estratificaçôes materiais e mentais (GUATTARI \& ROLNIK, 1996, p. 323).

Desterritorializaçôes e reterritorializaçăo sâo rizomáticos, bem como as linhas de fuga, uma vez que elas "náo param de se remeter uma às outras", garantindo a impossibilidade de uma lógica binária ancorada em dualismos e dicotomias, favorecendo o fluxo em rede, com caminhos múltiplos ou multiplicidades (DELEUZE \& GUATTARI, 2011 , p. 26). É a ideia do eterno devir - o que remete a Derrida (1986; 2011) sobre o eterno adiamento do sentido, deslizamento dos significantes - que é sempre desterritorializaçâo e reterritorializaçâo, sem fechamento, uma territorializaçăo é/está um/em constante movimento, adiamento. Săo novas formas de pensamento, novos conceitos, novos saberes que se (re)formam a partir de outros encontros, novas funçōes, novos arranjos, novos dispositivos - como os tecnológicos - e agenciamentos.

Lemos (2006, p. 8-9) afirma que as tecnologias, como dispositivos digitais móveis, dissolvem fronteiras, barreiras e hierarquias, "em um processo complexo de des-re-territorializaçôes", o que quer dizer que essas "tecnologias de comunicaçăo móveis desterritorializantes" sâo "instituintes de processos nômades, justamente por criar deslocamentos de corpos e informaçăo". Esses deslocamentos sucessivos e constantes abrem a possibilidade de o sujeito estar entre territórios, entre identidades, desterritorializando e reterritorializando, num movimento contínuo. Nos dias de hoje, essa possibilidade torna-se cada vez mais intensificada em decorrência, sobretudo, das tecnologias de comunicaçăo e informaçăo, que conectam sujeitos por meio da internet, sobrepondo a eles outras formas de pensar e agir, outros estilos de vida, outras representaçóes e identidade, como emerge nos recortes discursivos da análise, neste trabalho.

Com o intuito de dar conta do funcionamento do discurso sobre as tecnologias nos LDs de LI, integrantes do PNLD 2012, para o ensino médio, a análise parte da materialidade linguística que, no nível do intradiscurso, aponta para propriedades discursivas no interdiscurso. A análise discursiva e interpretativa permite compreender e problematizar os possíveis efeitos de sentido que emergem dos recortes selecionados que compóem o corpus de análise. A interpretaçăo é vista como "uma relaçăo mais de violência em relaçấo ao texto que de elucidaçăo" (FOUCAULT, 1997, p. 23), uma vez que o simples gesto do analista, ao fazer o recorte para a constituiçăo do corpus, já é interpretaçâo, já é o texto corroído, transformado. Porém, o processo de interpretaçâo nunca está acabado, encerrado no intérprete, uma vez que "năo há nada absolutamente primário a interpretar, porque no fundo já tudo é interpretaçăo, cada símbolo é em si mesmo năo a coisa que se oferece à interpretaçăo, mas a interpretaçăo de outros símbolos" (FOUCAULT, 1997, p. 22). O que há sâo interpretaçôes de interpretaçôes em um jogo infindável de gestos de interpretaçăo. 
Seguindo essa linha de raciocínio de que interpretar é ler, é lançar um olhar, é colocar algo de si, inferimos que interpretar é ato singular e subjetivo. No entanto, os sentidos nâo sáo dados a priori, mas construídos histórica e socialmente e, ainda regulados por instâncias que mantêm o poder e o saber (FOUCAULT, 1999) - propensos tanto à nova significaçâo como à ressignificaçăo. Assim, o sentido é dado à atualizaçăo, sendo possível capturar apenas seus efeitos, efeitos de sentido. É nesse sentido que empreendemos gestos analítico-interpretativos.

\section{ANÁLISE DOS RECORTES DISCURSIVOS}

O poder atinge o corpo social, năo mais vigiar para punir, mas vigiar para induzir, seduzir e como procedimento técnico "se inserir em seus gestos, suas atitudes, seus discursos, sua aprendizagem, sua vida quotidiana" (FOUCAULT, 1999, p. 74), conforme emerge no primeiro recorte em análise:

Figura 1: Alunas utilizando mídias digitais.

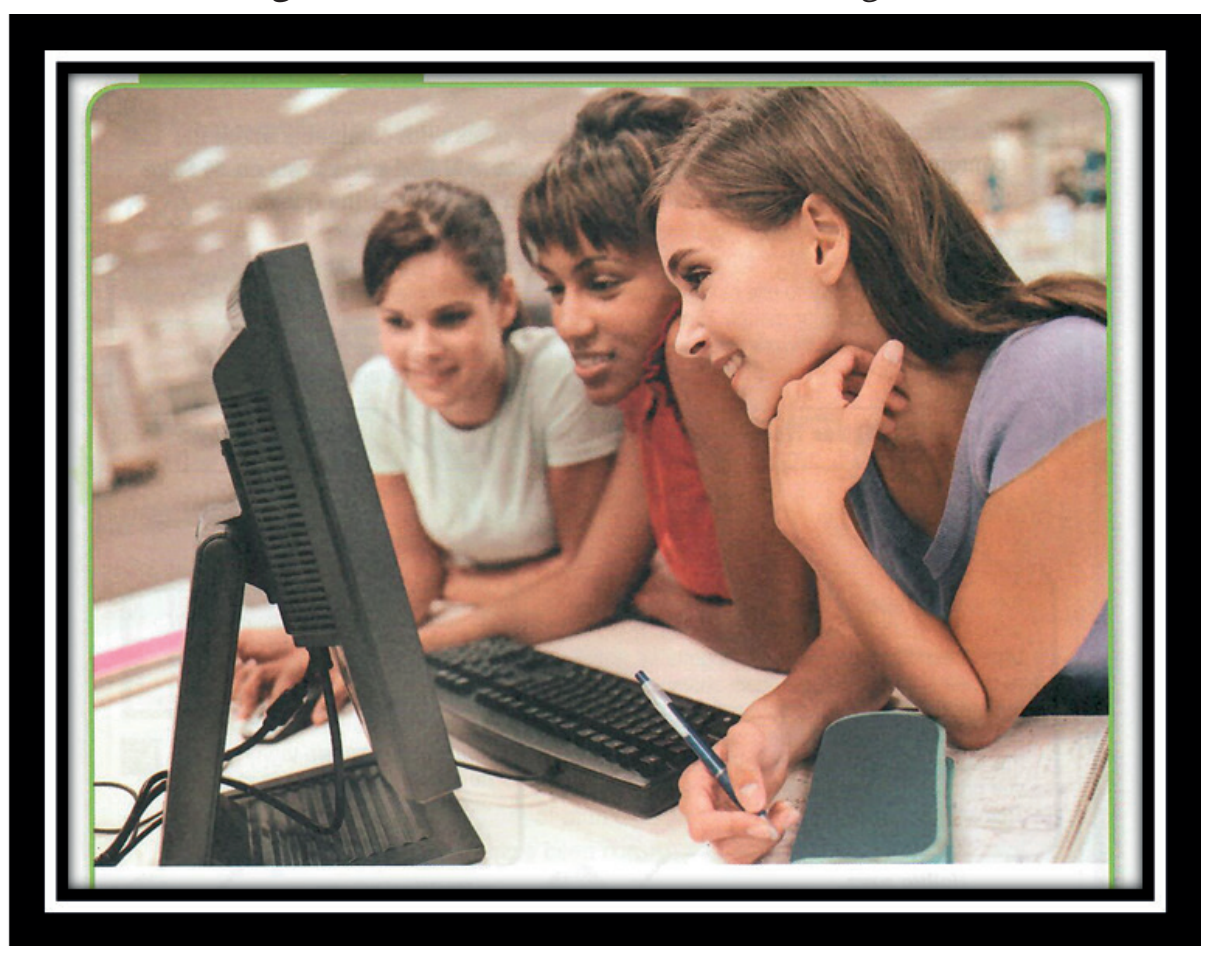

Fonte: PRIME 2, 2010, p. 178.

Este recorte discursivo encontra-se no livro Prime 2, na página 178, destinado à $2^{\mathrm{a}}$ série do ensino médio. A foto é utilizada em um exercício em que os usuários do material didático devem selecionar, entre várias opçóes, as características de blog. 0 recurso visual evidencia jovens estudantes numa relaçăo estreita, bem amigável com as novas tecnologias, na esfera educacional. As faces sorridentes, o brilho dos olhares atentos das três adolescentes, fixados na tela do computador, elucidam uma cena "encantadora", conforme divulgada no âmbito educacional, no que diz respeito à crença de que a internet propicia facilidades, aflora como uma soluçáo mais ampla para o 
alcance do saber de forma prazerosa e para a aquisiçăo de conhecimentos, pautada pelos regimentos oficiais de educaçấo, como podemos observar: "o Ministério da Educaçáo projetou o Proinfo, cujo principal objetivo é a introduçâo das Novas Tecnologias de Informaçăo e Comunicaçăo na escola pública, como ferramenta de apoio ao processo de ensino-aprendizagem" (BRASIL, 2006, p. 95).

O fato de a primeira garota, na foto ilustrativa, segurar uma caneta e, ao seu lado, sobre a mesa, estar uma agenda e um caderno com anotaçôes, indica que registros serâo feitos, levando-nos a crer que as garotas, possivelmente, realizam algum tipo de pesquisa escolar pela internet. A segunda garota, ao deslizar a măo sobre o mouse, mantém as demais com olhares atentos na tela do computador, o que dá a entender que elas realizam leitura na web, evocando efeitos de sentido de que săo sujeitos conectados e que sabem usar, adequadamente, os recursos disponíveis na página da web, de forma a encontrar com rapidez a informaçâo desejada, o que evoca a designaçáo de "nativos digitais" (PRENSKY, 2001).

O imaginário de que as novas tecnologias propiciam um saber cada vez maior é criado pelo modo como os discursos circulam e produzem sentidos na sociedade contemporânea em determinados espaços que os institucionalizam: seja nas diretrizes educacionais ou no LD de LI, ultrapassando as barreiras do impresso, caminhando na direçấo da materializaçăo da açăo em sala de aula, ou nas açôes cotidianas do aluno fora dos muros da escola. Pela foto apresentada pelo LD, o discurso sobre as "novas" tecnologias mobiliza açóes de práticas escolares que podem ser realizadas tanto no âmbito escolar quanto no âmbito residencial das estudantes.

A imagem parece convocar os alunos a fazerem uso das novas tecnologias, via seduçăo: a expressăo prazerosa, suave e de encantamento pelo que se vê na tela do computador é notória nas faces das estudantes, causando efeitos de sentido de que se os estudantes do ensino médio fizerem uso das ferramentas eletrônicas poderâo encontrar a mesma satisfaçăo. Dessa forma, o LD reforça o que sentenciam as Orientaçóes Curriculares - o uso das novas tecnologias "como ferramenta de apoio ao processo de ensino-aprendizagem" (BRASIL, 2006, p. 95), indiciando representaçóes de que o computador e a internet constituem-se em novas formas de desenvolver hábitos intelectuais na busca pelo conhecimento formalizado e legitimado.

Como a imagem apreendida pelo LD de LI nâo dá elementos esclarecedores da localidade onde se encontram as estudantes, aparentemente, em interaçấo com a tecnologia, seja no ambiente escolar ou residencial, o LD de LI faz representaçóes de que os alunos sâo sujeitos condizentes com a pós-modernidade: sujeitos com acessibilidade digital, que estudam em escolas equipadas com recursos informatizados: computador e banda larga para navegaçăo na internet. Ou ainda, o LD de LI provoca indícios de representaçôes de que suas residências podem ser/estar abastecidas dos recursos tecnológicos, possibilitando-lhes o acesso à informaçăo desejada.

A rede de sentidos que ainda se instala nesse recorte discursivo é de que as alunas năo têm necessidade de trabalhar, como forma de auxiliar na renda familiar, o que nâo seria comum em uma família que mantém seus filhos na rede pública de ensino. Como consequência, elas dispóem de tempo para a realizaçăo de afazeres escolares no ambiente residencial. Podemos, ainda, compreender que da foto ilustrativa das estudantes emanam efeitos de sentido de que elas têm o domínio das ferramentas digitais 
e as usam de forma interativa, cooperativa e autônoma, uma vez que elas realizam a pesquisa sem o auxílio do professor. A imagem, ainda, reforça a ideia de que oportunidades de inclusăo no mundo digital sâo oferecidas ao aluno do sistema público de ensino por meio do uso do material didático.

Enfim, podemos afirmar que as representaçôes trazidas pelo LD de LI podem nâo coincidir com a situaçăo de instalaçóes de equipamentos tecnológicos das escolas brasileiras nem com as das residências dos estudantes. Por mais que o LD se esforce para a tâo almejada inclusáo digital dos alunos, que utilize imagens que reforcem o uso das novas tecnologias "como ferramenta de apoio ao processo de ensino-aprendizagem" (BRASIL, 2006, p. 95), fazendo parecer que as novas tecnologias venham a exercer o poder e saber (FOUCAULT, 1999) no lugar do professor, ele pode criar um imaginário ilusório do que seria uma situaçăo desejada sobre a inserçăo das novas tecnologias no âmbito educacional.

As inovaçōes tecnológicas inseridas no contexto escolar por meio das ilustraçóes do LD de LI podem ser vistas pelos professores e alunos da rede pública como uma tentativa de incorporaçăo nas práticas pedagógicas de ambos, como uma maneira de provocar no aluno a vontade de realizar tais práticas, de modo que estas possam atingir o corpo, refinando "suas atitudes, seus discursos, sua aprendizagem, sua vida quotidiana" (FOUCAULT, 1999, p. 74), como uma forma de exercício do poder para a obtençăo do saber, constituindo uma verdade condizente com o momento histórico-social da (pós-) modernidade.

Outro fazer pedagógico que também é perpassado pela inserçăo das novas tecnologias como um suporte que proporciona "novas" formas de aprendizagem no âmbito escolar presentifica-se no recorte discursivo da Figura 2. Vale mencionar que ambos os recortes (o anterior e o próximo) utilizam a linguagem visual como uma tentativa de identificaçáo do aluno com o LD de LI. As fotos de adolescentes (anterior e posterior), com aparência da mesma faixa etária de alunos que estariam ou deveriam estar cursando a mesma série do ensino médio, parecem representar diferentes etnias: branca, parda e negra. Esse recurso utilizado pelo LD evidencia a tentativa năo só de realizar identificaçôes com os diferentes traços de etnias que, provavelmente, se fazem presentes na sala de aula, mas também como uma forma de atender às exigências do documento oficial para a elaboraçâo das coleçóes do PNLD: "isenta de estereótipos e preconceitos: social; regional; étnico-social; cultural; de gênero; de orientaçâo sexual; de idade" (BRASIL, 2011b, p. 16).

Com efeito, os alunos estariam se vendo, ao lançar um olhar para o outro (LACAN, 2007), nesse caso, representado pelo grupo de alunos frente ao computador. Estes despertariam neles (usuários do LD) o mesmo interesse mostrado pelo olhar atento das garotas (Figura 1), dos rapazes e da moça (na Figura 2), por algo que eles, aparentemente, veem na tela do computador, como se pode observar na figura abaixo: 
Figura 2: Alunos utilizando computadores para pesquisar na biblioteca

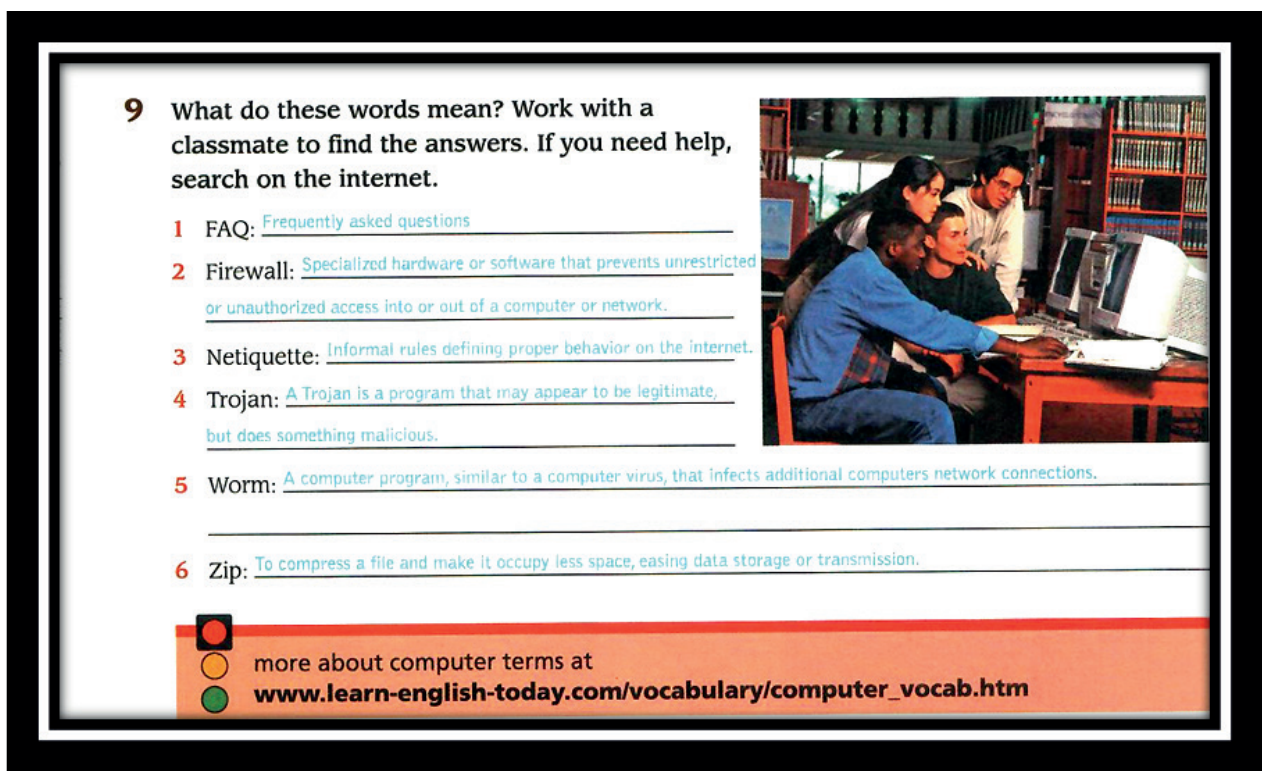

Fonte: Freeway 1, 2010, p. 73.

A atividade pedagógica integra a segunda seçăo, intitulada Accelerate, da Unit 5 Information Technology, da coletânea Freeway, do livro para a $1^{\text {a }}$ série do ensino médio. Essa seçâo tem a funçâo de apresentar "prática de leitura de modo contextualizado", seguido de atividades de interpretaçăo, bem como de exercícios que fomentam a "construçăo de contextos e referências culturais, para que o léxico, as funçôes e as estruturas gramaticais sejam apresentados, postos em prática e consolidados" (GUIA DIDÁTICO, 2010, p. 5). Sem a pretensáo de analisar se os "exercícios" correspondem às premissas básicas dessa seçăo, é de se notar que tais preceitos nâo se encontram de forma harmoniosa com o tipo de atividade pedagógica apresentada. Por se tratar de uma unidade temática sobre a tecnologia, o exercício traz palavras pertencentes a esse campo lexical, sem explorá-las nos contextos de uso.

Essa atividade é a nona de uma série de onze exercícios e, para responder o que essas palavras significam (what these words mean?), o aluno deve trabalhar com um colega de classe para encontrar as respostas (work with a classmate to find the answers). Essa sequência discursiva do enunciado da questâo aponta para representaçóes sobre alunos - para além daquelas de que o léxico apresentado nâo faz parte da vida cotidiana do aluno - que náo saberiam responder individualmente, devendo sempre trabalhar em grupo, de forma coletiva, apontando indícios de que o saber vem do outro, está no outro, ou com o outro. O trabalho em grupo é muito bem visto no âmbito empresarial - o saber trabalhar em equipe é uma qualidade, é garantia de sucesso - bem como no âmbito educacional. Mas ainda assim, ele pode precisar de ajuda (if you need help), transferindo o poder de saber o significado do léxico tecnológico para a própria máquina, já que a ajuda viria dela, ou melhor, da internet (search on the internet).

O fato de o LD apresentar um site para pesquisa, caso o aluno queira saber mais sobre os termos relacionados ao computador (more about computer terms at), ecoa efeitos de sentido de que na internet está năo só o que o LD de LI determina que os alunos "encontrem" (find) achem, se deparem, se defrontem - mesmo que quase por 
acaso -, mas também outros "tantos" termos relacionados ao mundo computacional. Além disso, o nome do site traz indícios de que para aprender inglês é preciso aprender a terminologia do campo tecnológico (www.learn-english-today.com/vocabulary/ computer_vocab.htm).

Pela foto ilustrativa da atividade pedagógica, depreendemos que os estudantes, apesar de estarem no espaço da biblioteca escolar, realizam pesquisa na internet. Apesar de as prateleiras estarem repletas de livros, năo é neles que os alunos buscam o significado da terminologia tecnológica. Também nâo é com os colegas de classe (classmate) que os alunos encontram as respostas para o que o LD de LI lhes pergunta (what these words mean?). Pelos olhares e corpos que convergem para a tela do computador 'velho' - diga-se de passagem, bem modesto, antigo -, parece que é lá que eles podem encontrar o que o LD de LI os instiga a buscar, o que aponta para uma espécie de submissâo a um saber que advém da máquina. Nessa imagem, ressoam efeitos de sentido de que o saber contido nos livros (da biblioteca) pode estar e, portanto, ser encontrado na máquina com acesso à internet.

A internet, inserida na sociedade contemporânea, tende a ocupar um espaço de poder-saber (FOUCAULT, 1999). Ao mostrar, na foto, os alunos com corpos e olhares inclinados para a tecnologia, rendidos a esses prazeres suscitados pela internet, o LD de LI tende a exercer uma espécie de captura, no aluno usuário do material, pelos olhares atentos, concentrados, lançados ao que se vê na tela: o saber encontrado, o gozo, o desejo saciado. Efeitos de sentido de que os olhares se curvam ao saber maquínico como uma forma de obtençăo de prazer; olhares que conclamam para o desenvolvimento de habilidades tecnológicas como forma de apropriaçăo do saber, do conhecer é, também, observado no próximo recorte - Figura 3.

A ilustraçấo analisada, tanto quanto, esta tende a funcionar como uma simulaçâo a ser incorporada no/pelo estudante, de forma que a situaçâo apresentada seja instaurada năo só no cotidiano escolar, mas também (abaixo) nos momentos de reflexăo da vida e de contemplaçáo do mundo, via internet, parecendo estabelecer uma relaçáo de encantamento e dominaçấo entre o homem, a tecnologia e o mundo:

Figura 3: 0 encantamento do homem.

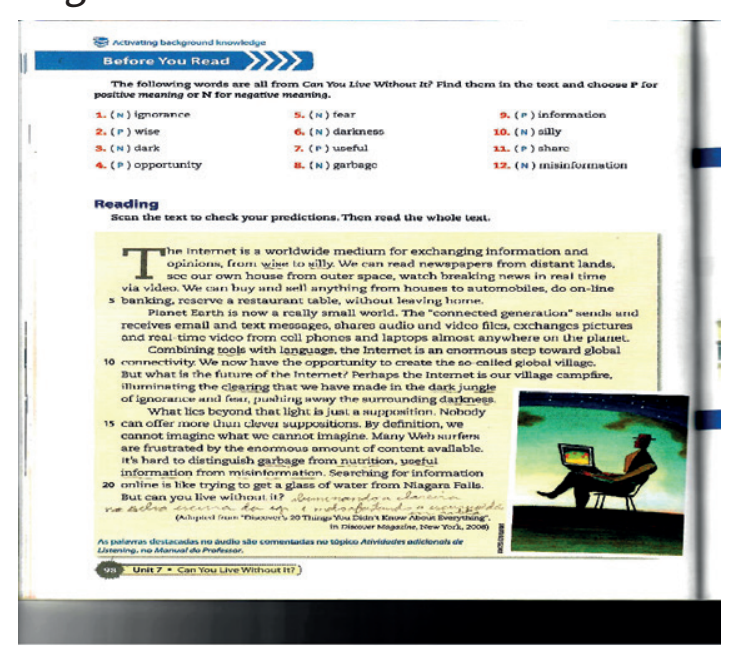

Fonte: On Stage 1, 2010, p. 98. 
Esta imagem ilustra o texto principal da unidade temática - Unit 7 - Can you live without it? - do LD de LI On Stage 1, do volume a ser trabalhado com a $1^{\text {a }}$ série do ensino médio. Nessa ilustraçăo, apresenta-se um homem que parece ser tăo virtual como a operacionalidade do computador: ele é uma sombra, imagem de homem, de um homem que náo existe mais. Um homem de porte e trajes elegantes, de forma alongada, de fino trato, parece ser a sombra de um verdadeiro gentleman, expressăo inglesa, que significa uma pessoa dotada de grande educaçấo e cultura, de boa família, com alta posiçấo social. É um exemplo a ser seguido, por se tratar de um indivíduo ideal de educaçáo e de personalidade refinada, caracterizado pelo autodomínio, altruísmo e coragem. É um homem que ocupa uma posiçâo elevada na sociedade, devido ao seu alto grau de instruçăo, conhecimento e cultura, parecendo, também, aqueles personagens de histórias em quadrinhos.

A maneira como o LD de LI posiciona essa imagem leva-nos a crer que há a tendência de querer estabelecer um sentido de que o saber adquirido via máquina é um saber diferenciado, um saber que tem o poder de transforma(ta)çáo do sujeito, a ponto de ele vir a ser outro, o outro que a sociedade deseja, o outro da ficçáo, da simulaçấo, esse outro que se (con)funde com o da realidade, no futuro da vida do aluno usuário do material didático.

Esse deslocamento parece conduzir o aluno a lançar-se na dispersăo do mundo virtual, lugar onde o corpo tende a se desterritorializar (GUATTARI \& ROLNIK, 1996) por meio de um olhar que se virtualiza em um espaço transcendental, onde a realidade ganha outra dimensăo, passível de dominaçăo. O estar só e sempre conectado é condiçâo para a garantia e manutençáo do controle de si e do outro (TURKLE, 2011), como parece apontar năo só o lugar onde o homem (corpo) se encontra, como também pelo que se vê (olhar) na tela do computador - o globo terrestre -, evidenciando uma dimensâo maior: a ilusâo de dominaçăo do mundo através da tecnologia. Desse modo, as novas tecnologias parecem propiciar a condiçấo do processo de governamentalidade (FOUCAULT, 1999), o que concede uma falsa sensaçăo de liberdade e autonomia, de governo de si e do outro, como formas de controle, de conduta.

Essa imagem de corpo que se desterritorializa (o homem que parece estar no centro do universo) e de olhar que se virtualiza (a imagem do globo terrestre na tela do computador) parecem funcionar como formas de agenciamento, em que o sujeito é convocado a assumir uma nova posiçáo diante das novas tecnologias, o que permite, quase que inconscientemente, que elas controlem suas vidas, na ânsia de achar que a máquina, assim como o mundo, é controlada pelo sujeito. Nesse sentido, as novas tecnologias passam a funcionar como dispositivos de normas, condutas, agenciando o sujeito, ao estabelecer uma relaçấo de desejo consigo mesmo. Quanto maior o manejo da tecnologia, maior o conhecimento via maquinaria, maior é seu estado de dominaçăo, estado esse de (con)fusâo em que o sujeito nâo sabe se é ele quem domina ou se é dominado.

Em decorrência disso, a internet parece funcionar como um objeto capaz de satisfazer um desejo, como um produto de multiplicaçâo em razâo de seu alcance global, mundial, como sugerido pela imagem ancorada no discurso da globalizaçáo, discurso fabricado via relaçôes de poder, que produzem regimes de verdade, verdades que induzem ao prazer. Nessa perspectiva, a internet é vista como um dispositivo de controle, que exerce determinados "efeitos de poder", năo via repressăo, mas via seduçâo como 
"uma nova "economia" do poder, isto é, procedimentos que permitem fazer circular os efeitos de poder de forma ao mesmo tempo contínua, ininterrupta, adaptada e "individualizada" em todo o corpo social" (FOUCAULT, 1999, p. 8). Outro recorte que produz efeitos de poder e seduçấo via maquinaria pode ser observado na Figura 4:

Figura 4: Jog’o de vídeo g’ame: a ilusão de ótica.

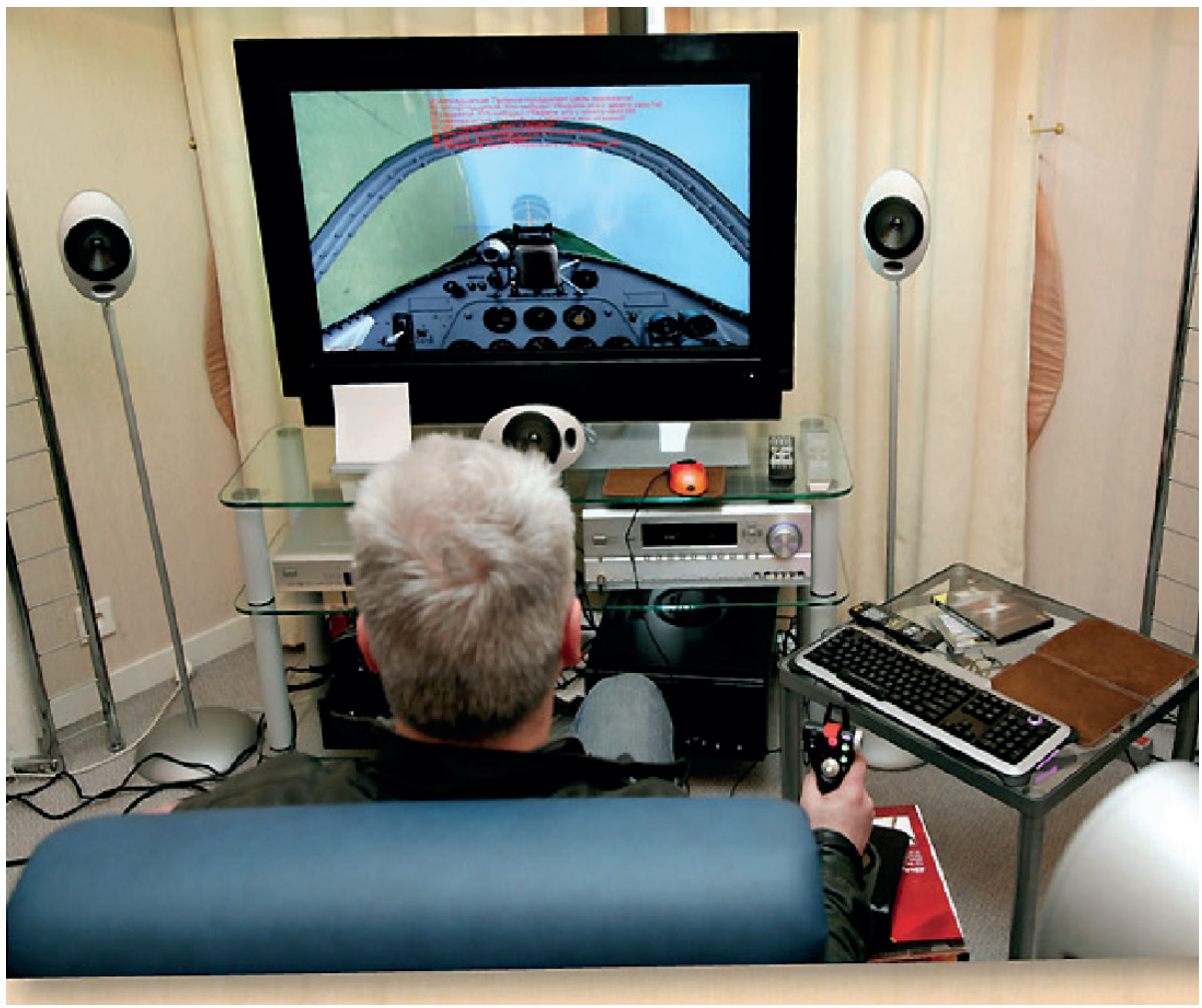

(RD-4) Prime 3, 2010, p. 36.

A imagem ilustrativa do texto A day in the life of a game developer, ${ }^{2}$ da seçâo Carer Spot, do LD de LI Prime, destinado à $3^{a}$ série do ensino médio, mostra um adulto, já com certa idade - é o que aparenta pelo aspecto da cor de seu cabelo - no comando de jogos on-line, em uma sala equipada com "modernos" aparelhos tecnológicos de som, como o home theater e visual, como a TV com conexăo à internet, onde se projeta melhor a imagem, principalmente, se comparado com a tela do computador, dada a sua amplitude. Vale mencionar que a seçâo Career Spot tem o propósito de "colocar os alunos do Ensino Médio em contato mais direto com algumas opçóes de trabalho, notadamente aquelas que, por sua natureza, ofereçam oportunidades de comunicaçâo em língua inglesa" (TEACHER'S GUIDE, 2010, p. 5). Observamos também que a maioria dessas profissóes está relacionada, de alguma forma, com as novas tecnologias.

No mundo globalizado e tecnológico, o conhecimento da língua inglesa é pré-requisito para o exercício da profissáo Programador de Jogos - Game Developer -, uma vez que há poucos livros sobre programaçăo de jogos em português e os que existem

Traduçăo nossa: Um dia na vida de um programador de jogos. 
săo classificados como desatualizados. Apesar dos cursos de graduaçăo e dos cursos de nível técnico existentes, uma das maneiras de aprender é através da internet (fóruns, blogs, sites, tutoriais, vídeos e cursos gratuitos online). Além de ter a funçâo de programar, modificar e explicar como o código dos games funciona, o programador de jogos on-line deve ser, antes de qualquer coisa, um "excelente" e experiente jogador de games digitais, como bem representa a foto, apontando mais para uma situaçăo de lazer que de trabalho, situaçăo frequente no cotidiano atual.

Diante do exposto, ao trazer uma profissáo que necessita, basicamente, da língua inglesa e de linguagens técnicas e específicas de programaçăo e desenvolvimento de games digitais, parece que o LD de LI constrói representaçôes sobre os alunos como sendo năo só aqueles que gastam tempo de suas vidas jogando na internet - nativos digitais (PRENSKY, 2001) -, mas também como aqueles que podem se interessar por esse tipo de profissăo, considerando que, além de ser uma profissăo rentável, está em desenvolvimento no nosso país. Uma das formas de motivaçâo e seduçăo para atrair o estudante é notada na maneira como a sala está equipada com aparelhos tecnológicos, podendo exercer fascínio no aluno, despertar o desejo de possuí-los, de consumi-los. O estudante é tratado como um consumidor em potencial - das novas tecnologias e da língua inglesa - uma vez que vemos, nessa imagem, como uma "operaçăo (que) consiste em apelar para a dimensâo do desejo, que é singular, e responder a ela como fetiche da mercadoria" (KEHL, 2004, p. 50).

Nesse recorte discursivo, como nos anteriores, o olhar se curva para o aparelho tecnológico, onde se vê um painel de controle de aviăo e, bem à sua frente, o seu próprio comandante, que é observado por três olhos biônicos, representados pelas caixas de som do aparelho home theater que, por sua vez, representam os olhares dos telespectadores, duas caixas posicionadas nas laterais da sala e uma na frente de seu suposto comandante, o game developer. Situaçăo de comando, de centralidade, de objetividade de um sujeito consciente e presente que carrega a ilusăo de que a imagem-objeto está sob o controle de seus olhos e de sua mâo, operacionalizando o joystick - o controlador do jogo - com vários botôes: basta acioná-los para obter movimentos para cima e para baixo, para a direita e para a esquerda.

Sujeito, imagem e objeto se entrelaçam, se desenlaçam, e se imbricam. A simulaçăo do objeto torna-se imagem-objeto, "mas também imagem-linguagem, vaivém entre programa e tela [...] reage interativamente ao nosso contato, mesmo ao nosso olhar: ela também nos olha" (COUCHOT, 2011, p. 42), uma vez que ela é olhada por nós, funcionando como o "eterno retorno" - a cada olhar, o que se repete traz uma marca do diferente. $\mathrm{O}$ jogador que comanda os movimentos da imagem-máquina sucumbe aos movimentos dos quais a máquina foi incumbida pelo programador, proporcionando tanto ao jogador quanto ao programador uma ilusấo de controle, de poder e de saber: poder, saber e controle que se imbricam no homem-máquina, na máquina-homem, via linguagem/língua inglesa e tecnologia.

A imagem (re-)apresenta uma simulaçâo virtual de que se pilota um aviâo, de que este está na mira do controle, momento em que se confunde realidade com ficçấo. É a realidade de se pilotar um aviăo projetada na tela do computador, portanto, reconstruída na simulaçăo virtual. A disposiçăo do aparelho de TV, num canto da sala, e o lugar que o jogador ocupa na sala causam-nos a impressăo/sensaçăo de que se trata de 
uma cabine de aviăo e o jogador-programador é o piloto, aquele que tem o domínio da língua inglesa e da tecnologia. Nesse jogo de imagens, parece que o aluno é convocado a seguir o modelo apresentado, correspondendo a "simulacros de simulaçăo, baseados na informaçăo, no modelo, no jogo cibernético - operacionalidade total, hiper-realidade, objectivo de controle total" (BAUDRILLARD, 1991, p. 151), nâo só da máquina, mas também do sistema educacional de ensino.

\section{CONSIDERAÇÕES FINAIS}

Esta pesquisa se desenvolveu a partir da investigaçăo sobre a maneira como se dá a apropriaçấo do discurso sobre as "novas" tecnologias por materiais didáticos de língua inglesa, integrantes do Programa Nacional do Livro Didático - PNLD 2012. A problematizaçăo mostrou como tanto o discurso político educacional quanto o discurso didático pedagógico se apropriam do discurso contemporâneo sobre as "novas" tecnologias. Esse percurso conduziu à observaçấo de que o sujeito enunciador - o autor do LD de LI - constrói representaçôes que nâo só se restringem às novas tecnologias, mas que também aliciam o aluno a ter uma determinada posiçăo.

A análise partiu da materialidade linguística que, no nível do intradiscurso, aponta para propriedades discursivas no interdiscurso, o que possibilitou compreender o funcionamento do discurso sobre as chamadas novas tecnologias no LD de LI, para o ensino médio. Vale mencionar o seu recobrimento em relaçăo à profissăo tecnológica para jovens, como modo de apropriaçáo do discurso sobre as "novas" tecnologias, como game developer (programador de jogos). Esse posicionamento do LD de LI atesta seu cumprimento a uma demanda do discurso político educacional que atribui à escola a funçâo de preparar o aluno para o ingresso no mercado de trabalho tecnológico (BRASIL, 2006).

Os efeitos de sentido de deslocamento do saber, do conhecimento e da informaçáo veiculados nas ilustraçōes das atividades pedagógicas vêm à tona: apesar de os alunos ocuparem o espaço de bibliotecas escolares, abarrotadas de livros, realizam pesquisa via computadores e internet, como se eles fossem a maior biblioteca do mundo, o substituto para os livros, a maior simulaçăo de arquivo do saber humano. Rastreando na materialidade linguística năo verbal, efeitos de sentido constitutivos de representaçōes sobre o aluno como sendo um nativo digital (PRENSKY, 2001) ecoaram: eles sâo usuários assíduos de ferramentas eletrônicas, como os computadores e a internet na realizaçăo de afazeres escolares.

Ainda, o discurso sobre as "novas" tecnologias (re-)apresentam-nas, para o aluno, como possibilidades de aprendizagem da LI, de inserçâo no mundo globalizado e digital, e como corolário, a sua integraçăo no mundo do trabalho e a ascensâo social. Tais efeitos de sentido permeiam o discurso político educacional que, por sua vez, fazem eco no discurso didático pedagógico. Dito diferentemente, é o discurso político educacional agindo sobre o discurso didático pedagógico. A açăo daquele discurso sobre este gera poder e, consequentemente, saber; planificam-se relaçōes intrínsecas entre poder-saber (FOUCAULT, 1999) estabilizadoras do funcionamento do discurso de verdade.

As imagens ilustrativas impregnadas, nos recortes discursivos analisados, de jovens atraentes, satisfeitos, fascinados e deslumbrados pelas novas tecnologias atribuem a elas certo empoderamento, como se elas fossem capazes de desenvolver, no 
estudante, hábitos intelectuais na busca pelo conhecimento formalizado e legitimado. Essas imagens evocam representaçóes de alunos que realizam pesquisa em sala de aula de forma autônoma, livre: sem a presença do professor, fazem seu dever escolar em casas abastecidas de equipamentos tecnológicos, reunindo prazer, satisfaçấo e gozo pelo saber e lazer alcançados. Para além de um querer representar as novas tecnologias como algo novo e diferente que agenciam novos modos, condutas e saberes do aluno, defendemos que, nos recortes analisados, elas exercem a funçăo de captura, de tentativas de seduçăo, de dispositivos de controle do ensinar e aprender autônomos.

Apesar de as "novas" tecnologias fazerem parte de um processo da rede complexa de constituiçấo do sujeito da (pós-)modernidade, defendemos o posicionamento de estado de alerta em relaçáo ao atravessamento do discurso sobre as "novas" tecnologias no discurso político educacional e, por sua vez, no discurso didático pedagógico. Esse movimento discursivo năo está isento de jogos de interesses político e econômico, na medida em que se busca o saber e, como consequência, mantém-se o exercício do poder, como pensado e articulado por Foucault (1999). 


\section{REFERÊNCIAS}

BAUDRILLARD, J. Simulacros e simulaçōes. Trad.: Maria Joăo da Costa Pereira. Lisboa: Relógio D'Água, 1991.

BRASIL. SECRETARIA DE EDUCAÇĀO FUNDAMENTAL. Orientaçōes Curriculares para o Ensino Médio: Linguagens, Códigos e suas Tecnologias. Brasília: MEC; SEMTEC, 2006.

BRASIL. SECRETARIA DE EDUCAÇĀO FUNDAMENTAL. Ministério da Educaçâo. Fundo Nacional de Desenvolvimento da Educaçâo: FNDE. Edital de Convocaçâo para Inscriçáo no Processo de Avaliaçáo e Seleçáo de Coleçóes Didáticas, para o Programa Nacional do Livro Didático - PNLD 2012, 2011 a.

BRASIL. SECRETARIA DE EDUCAÇĀO FUNDAMENTAL. Ministério da Educaçâo. Guia de livros didáticos: PNLD 2012: Língua Estrangeira Moderna. Brasília: Ministério da Educaçâo, Secretaria de Educaçấo Básica, 2011b.

CORACINI, M. J. As representaçōes do saber científico na constituiçâo da identidade do sujeito-professor e do discurso da sala de aula. In: CORACINI, M. J. (Org.). Identidade e discurso: (des)construindo subjetividades. Campinas: Unicamp; Chapecó: Argos Editora Universitária, 2003a, pp. 319-336.

CORACINI, M. J. O (a) professor(a) de língua portuguesa entre preplexidades e (des) encantos. In: CORACINI, M. J. (Org.). Identidade e discurso: (des)construindo subjetividades. Campinas: Unicamp; Chapecó: Argos Editora Universitária, 2003b, pp. 238-255.

CORACINI, M. J. O olhar da ciência e a construçâo da identidade do professor de língua. In: BERTOLDO, E. S.; CORACINI, M. J. (Orgs.). 0 desejo da teoria e a contingência da prática: discursos sobre e na sala de aula (língua materna e língua estrangeira). Campinas: Mercado de Letras, 2003c, pp. 193-210.

CORACINI, M. J. A celebraçâo do outro: arquivo, memória e identidade: línguas (materna e estrangeira), plurilinguismo e traduçăo. Campinas: Mercado de Letras, 2007.

CORACINI, M. J. Discurso e escrit(ur)a: entre a necessidade e a impossibilidade de ensinar. In: CORACINI, M. J.; ECKERT-HOFF. B. M. (Orgs.). Escrit(ur)a de si e alteridade no espaço papel-tela: alfabetizaçấo, formaçăo de professores, línguas materna e estrangeira. Campinas: Mercado de Letras, 2010, pp. 17-50.

CORACINI, M. J. (Org.). Interpretaçăo, autoria e legitimaçăo do livro didático: língua materna e língua estrangeira. 2. ed. Campinas: Pontes Editores, 2011.

COUCHOT, E. Da representaçâo à simulaçâo: evoluçâo das técnicas e das artes da figuraçăo. In: Imagem-máquina: a era das tecnologias do virtual. PARENTE, A. (Org.). Trad. Rogério Luz et al. 4.ed. Rio de Janeiro: Editora 34, 2011.

DELEUZE, G. O que é um Dispositivo. In: DELEUZE, G. O Mistério de Ariana. Cinco Textos e uma Entrevista de Gilles Deleuze. Trad. Edmundo Cordeiro. Lisboa: Vega, 1996.

DELEUZE, G.; GUATTARI, F. Mil platôs: capitalismo e esquizofrenia. Vol. 1. Trad. Ana Lúcia de Oliveira, Aurélio Guerra Neto e Celia Pinto Costa. 2. ed. Săo Paulo: Editora 34, 2011. 
DERRIDA, J. Margens da Filosofia. Trad. Joaquim Torres Costa e António M. Magalhāes. Porto: RÉS Editora, 1986.

DERRIDA, J. Gramatologia. Trad. Miriam Chnaiderman e Renato Janine Ribeiro. Sáo Paulo: Perspectiva, 2011.

DERRIDA, J. Pensar em năo ver: escritos sobre as artes do visível (1979- 2004). (Org.) MICHAUD, G.; MASÓ, J.; BASSAS, J. Trad. Marcelo Jacques de Moraes. Revisăo técnica de Joâo Camillo Penna. Florianópolis: Editora UFSC, 2012.

FOUCAULT, M. A ordem do discurso. Trad. Laura Fraga de Almeida Sampaio. 12. ed. Sáo Paulo: Loyala, 1995a.

FOUCAULT, M. O sujeito e o poder. In: DREYFUS, H.; RABINOW, P. Michel Foucault, uma trajetória filosófica: para além do estruturalismo e da hermenêutica. Rio de Janeiro: Forense Universitária, 1995b, pp. 231-249.

FOUCAULT, M. Nietzsche, Marx e Freud - theatrum philosoficum. Trad. Jorge Lima Barreto. Sấo Paulo: Editora Princípio, 1997.

FOUCAULT, M. Microfísica do poder. Trad. Roberto Machado. 14. ed. Rio de Janeiro: Graal, 1999.

FOUCAULT, M. A arqueologia do saber. Trad. Luis Felipe Baeta Neves. 7. ed. Rio de Janeiro: Forense Universitária, 2009a.

FOUCAULT, M. O que é um autor? In: FOUCAULT, M. Ditos e escritos: estética - literatura e pintura, música e cinema (Vol. III). Trad. Inês Autran Dourado Barbosa. Rio de Janeiro: Forense Universitária, 2009b, pp. 264-298.

GUATTARI, F.; ROLNIK, S. Micropolítica: cartografias do desejo. Petrópolis: Vozes, 1996.

KEHL, M. R. O espetáculo como meio de subjetivaçâo. In: BUCCI, A.; KEHL. M. R. (Org.). Videologias: ensaios sobre a televisâo. Săo Paulo: Boitempo, 2004, pp. 43-62.

LACAN, J. 0 seminário, livro 23: O sinthoma. Trad. Sergio Laia. Rio de Janeiro: Zahar, 2007. LACAN, J. 0 seminário, livro 16: de um outro ao outro. Trad. Vera Ribeiro. Rio de Janeiro: Jorge Zahar, 2008.

LEMOS, A. Ciberespaço e tecnologias móveis: processos de territorializaçăo desterritorializaçăo na cibercultura. In: Encontro Anual da COMPÓs - Associaçāo Nacional dos Programas de Pós-Graduaçâo em Comunicaçăo. 15., Bauru. UNESP-Bauru, 2006. Disponível em: www.facom.ufba. br/ciber pesquisa/andrelemos/territorio.pdf. Acesso em: 29 jan. de 2016.

MASCIA, M. A. A. Investigaçóes discursivas na pós-modernidade: uma análise das relaçôes de poder-saber do discurso político educacional de língua estrangeira. Campinas: Mercado de Letras, Săo Paulo: Fapesp, 2002.

NASIO, J. D. Liçóes sobre os 7 conceitos cruciais da Psicanálise. Trad. Vera Ribeiro. Rio de Janeiro: Zahar, 1997.

PRENSKY, M. Nativos digitais, imigrantes digitais. Trad. Roberta de Moraes Jesus de Souza. On the Horizon - NCB University Press, v. 9, n. 5, 2001. Disponível em www. Marcprensky.com/.../ Prensky\% 20-\%20Digital\%20Nativos. Acesso em: 13 mar. de 2011. 
SALUM, A. C. C. Redes virtuais de relacionamento: dispositivos de subjetivaçâo, individuaçâo e controle. 2012. Tese (Doutorado em Linguística Aplicada) - Universidade Estadual de Campinas, Instituto de Estudos da Linguagem, Campinas, 2012.

TURKLE, S. Life on the screen: identity on the age of the Internet. London: Weidenfel \& Nicolson, 1996.

TURKLE, S. Alone together: why we expect more from technology and less from each other. New York: Basic Books, 2011.

\section{REFERÊNCIAS DO CORPUS}

DIAS, R.; LEMOS, A.; FARIA, R.; JUCA, L. Prime: inglês para o ensino médio. 2. ed. Sâo Paulo: Macmillan, 2010.

MARQUES, A. On Stage: ensino médio. Sâo Paulo: Ática, 2010.

TEODOROV. V. Freeway. São Paulo: Richmond, 2010. 